\title{
Towards an uncertain future? The strengthening of Japan's autonomy in Asia-Pacific
}

\author{
Em direção a um futuro incerto? O fortalecimento \\ da autonomia do Japão no Pacífico asiático
}

http://dx.doi.org/10.1590/0034-7329201400106

SHIGUENOLI MIYAMOTO*

PAULO DANIEL WATANABE**

Rev. Bras. Polít. Int. 57 (1): 98-116 [2014]

Aspiring sincerely to an international peace based on justice and order, the Japanese people forever renounce war as a sovereign right of the nation and the threat or use of force as means of settling international disputes.

In order to accomplish the aim of the preceding paragraph, land, sea, and air forces, as well as other war potential, will never be maintained. The right of belligerency of the state will not be recognized.

(Article Nine, Japanese Constitution)

Recently, Japan has been increasing tensions with China regarding the Pinnacle Islands ${ }^{1}$, which is called Senkaku by the Japanese and Diaoyu by the Chinese. In September 2012, a few months after the $40^{\text {th }}$ anniversary of the normalization of the diplomatic relations between both countries, the government of Japan under the Democratic Party of Japan (DPJ) declared the purchase of some of the disputed islets, which was denounced by China as illegal and subject to retaliations. Obviously this response from China was clearly foreseen and expected. Nevertheless, even under verbal attacks by Chinese civilians, the Japanese government maintains its stance, claiming that there was no illegal act since those islands are part of the Japanese territory. It claims that the change of the status from private to public would not change a thing in international affairs. Yes, it would not change a thing if there was no open dispute; however, it shows that Japan does not believe that there is a real claim from China. The reason for this could be that it intends to make its sovereignty over the islands a commonly

* State University of Campinas (Unicamp), Campinas, SP, Brazil (shiguenoli@gmail.com).

** São Paulo State University (Unesp), São Paulo, SP, Brazil (p.daniel.w@uol.com.br).

1 Neutrally, these islets are named Pinnacle Islands. 
accepted custom in International Law, an action that is clearly prevented by the continuous Chinese claims. ${ }^{2}$

This shows that Japan is not willing to accept the Chinese pressures on its interests or on any other subject. It may not seem like a lot, but it surely is. As a security issue, Japan seems to be alone in this territorial dispute. Washington insists in not taking sides publicly in this issue, but former US Secretary of Defense Leon Panetta had indicated that in the worst scenario, which could mean a military dispute, the Pinnacle Islands would be covered by the US-Japan Security Treaty, since it is under the effective control of Japan. ${ }^{3}$

Although there is an old military alliance behind this dispute, it is not likely that the US would be willing to use its military forces to tip the balance in favor of Tokyo or show preparedness for a possible armed conflict with China. Nevertheless the Chinese think the opposite: without US support, Japan will stop its provocative actions. Naturally, Washington will press Tokyo to lower tensions if there is, somehow, a chance of armed conflict over the territorial issue. The same happens in the dispute over the Northern islands controlled by Russia since the end of World War II, which are claimed by Japan. In the latter case, however, all Japan can do is claim those islands just like China does for the Pinnacle Islands.

The purchase of the islets represents one of the many signals that Japan wants to restore its power in Asia and face the Chinese growth in a containment strategy; first because the purchase was unnecessary to the Japanese side, once it already had the effective control over them and, second, because it only heightened tensions with the Chinese government and civilians. That was only an act of vanity. The Japanese government, under Foreign Minister Gemba Koichiro (DPJ), claimed that the objective of the purchase was to minimize any adverse impact on the Japan-China relationship and that it was the only viable option to protect bilateral relations (Gemba 2012). Exactly the opposite happened.

The rebirth of the Japanese activeness and assertiveness has been perceived since the beginning of the $21^{\text {st }}$ century, led by politicians considered "revisionists," who tried to expand the legal and technical capabilities of the Japan Self-Defense Forces.

During the last decades, despite the military alliance with Washington, Tokyo learned that a full capable military is important to support political actions, especially those towards the UN. The image of the Checkbook Diplomacy from the Gulf War in the early 1990s made Japan look like an irresponsible power; it was one of the most interested countries in the oil from the Middle East, but it could not help (or at that time it saw no importance in doing so) the international

2 Japan and China have been dealing with the disputed islets since the negotiations for the diplomatic normalizations in the 1970s. This issue was shelved by both countries. It was said to be a single problem that should not jeopardize the normalization of diplomatic ties.

3 On April 23, 2014, President Obama said in a written response to the Japanese Newspaper Yomiuri Shinbum that those islands are under the US-Japan treaty, since they are administered by Japan. 
community put things in order. Other nations sent people to risk their lives and, possibly, die; Japan sent dollars. Instead of a pacific power (or civilian power, as some argue), Japan was an incomplete great power.

As the former Defense minister of Brazil, Nelson Jobim once said "having a good defense is having the capability to say 'no' when it is necessary." It is not easy or even possible to measure how powerful Japan is or can be. Since 1947, when the current Constitution went into effect, it has been subject to different interpretations, sometimes contradictious to prior understandings. As an example, to Yoshida Shigeru — the third Prime-Minister, who created a diplomatic thinking which was named after him and led the Japanese Foreign Policy for decades-, after the end of WWII the use of jets would be forbidden by the Constitution. Nowadays Mitsubishi manufactures aircrafts similar to the American F-15 for the Japan Self-Defense Air Force. In 1995 the government published the New National Defense Program Outline (NNDPO), which reaffirmed the interest in having basic capabilities for defense and states that the Self-Defense Forces must act in order to neutralize indirect aggressions in its roots. A "preventive defense" should be allowed under this perspective. "Preventive attacks," what might be the same thing in practice, are expected to be unconstitutional. The ambiguous Article Nine of the Constitution gives the government chances for political maneuvers. ${ }^{4}$

Although those changes in the Japanese defense does not appear to be tangible or substantial in a certain way, Beijing fears that new defensive roles for Japan could break important norms of self-restraint, leading to more comprehensive military buildups (Christensen 1999). Japan may not be a military power now, but it will certainly be someday, even under the postwar Constitution. Naturally, this is felt by other neighbors too, not only China.

Since Japan may be on its way to remilitarization, China has an important role in this process. China's behavior in the Pinnacle dispute may set Japan's relations in Asia, since this dispute is raising tensions on both sides. Both want to express their position no matter what. Japanese politicians are not willing to acquiesce.

\section{Postwar Japan: a silent, rich country}

Japan's postwar foreign policy was led by a hegemonic way of thinking named the Yoshida Doctrine. As said before, Yoshida Shigeru was the third Prime-Minister after Japan's surrender and he was the one responsible for the adoption of the new Constitution and the close relationship with the United States. In few words, the Yoshida Doctrine focused the highest state priority on the economic recovery while keeping a silent behavior in international politics. It meant that all other

4 In mid-February 2013, after North Korean nuclear tests, Japan's Ministry of Defense Onodera Itsunori informed Reuters in an interview that Japan has the right to make preemptive attacks: "When an intention to attack Japan is evident, the threat is imminent, and there are no other options, Japan is allowed under the law to carry out strikes against enemy targets." 
expenditures would not be given much or any attention. The main abandoned area was defense, which became an American responsibility in 1951, when Japan and the United States signed a security treaty in order to restore the Japanese sovereignty after the seven-year occupation.

Obviously there were good reasons for Yoshida to pass on this responsibility to another country. First, the understandings of the Constitution at that time allowed no military forces. Second, the Japanese state could invest all the resources on other sectors such as industry and education. Third, having the anti-war clause in the Constitution (and respecting it) would permit Japan to reintegrate the international system in a less-hostile environment due to the World War II antagonisms. In his memoirs, Yoshida says: "the renunciation of war, even in selfdefense, was therefore a necessary step in order to rectify this wrong impression, held by other nations, of our aims and intentions." (Yoshida 1961, 115). ${ }^{5}$

For the United States, by the end of the occupation, Japan was already a trustworthy ally, but this was not clear until 1947. The two main goals of the occupation, demilitarization and democratization, were already reached or were on their way. The problem was the economic situation. The postwar economy of Japan was almost dead. The country was facing 700\% inflation and in 1948 the industries could not reach a third of the total prewar production (Sugita 2003, 50). The Japanese capitalists did not want to invest in industries because the Occupation Forces had been dissolving all of the industrial complexes since the end of the war. It was sensible to wait and see what came next (Dower 1979). It was then realized that Japan's economic situation could dangerously lead it to another sphere of influence: that of the Soviet Union. Sugita Yoneyuki (2003) argues that the pro-American tendency and the anti-Soviet feelings could be reverted due to the economic crisis. The Japanese would stop believing in democracy. This is why the American Government sent Joseph Dodge from the Bank of Detroit to Japan, to create a new economic plan. This plan was named the Dodge Plan and looked forward to the stabilization of the Japanese economy. Along with the Dodge Plan, it is important to mention that the Korean War in the early 1950s also helped Japan recover its economy.

Since it had a good and trustworthy ally, Japan did not need to worry about its security. The Cold War gave it the opportunity to develop its heavy industries and be protected by the nuclear umbrella of the United States. At the same time, Japan avoided involving itself in international politics, since it could not be committed to international security.

This "free ride" had a price. During the Cold War, it was important and useful. In the 1970s, Japan's GDP was higher than France's and the United Kingdom's together (Kennedy 1989). But the Yoshida Doctrine continued to be Japan's grand strategy for foreign policy. In the 1990s, Japan realized that, despite

5 The origin of Article Nine is unknown. Some argue that it was General MacArthur's ideas. Others argue that it was Prime-Minister Shidehara's idea. 
being an economic great power, it was a political dwarf. The Gulf War required Japan's contributions, which did not go beyond the financial sphere. The result was the expected one: Japan became an economic giant, but it was marginalized in international politics and seen as an American puppet.

As for the United States, maintaining Japan as an ally and consequently protecting it was the only possibility. In 1949, when the Chinese communists expelled Chiang Kai-Shek and his followers to Taiwan, the US realized that Japan would be the only and valid bet in East Asia to support the containment. The US tried to rearm Japan. It was an issue discussed during the negotiations for the end of the occupation. Dower states that:

On June 25, 1950, war erupted in neighboring Korea; and the United States, only four years after imposing its "peace constitution," hastened to impose remilitarization on a reluctant nation even as its war-related purchase gave a transfusion to the country's anemic economy. [...] The conflict in Korea ushered in a new world; and for the first time since the surrender Japan, willing or not, was distinctly part of this world. (Dower 1999, 526).

Inoguchi Takashi, professor of Political Science at the University of Tokyo, wrote an article in 1989 titled Four Japanese Scenarios for the future, in which he states:

Bereft of a sense of direction, and uncertain about the future, Japan has been haunted by a vague angst about its future which has led it sometimes to hedge, and at least to limit its commitment to the demands, requests and suggestions coming from overseas that Japan, now a global economic power, should take on more global responsibility. (Inoguchi 1989).

After the Gulf War in the 1990s, it was clear that if Japan wanted to be a real great power, it had to improve its capacities. This change had to keep all the neighbors calm and show no aggressiveness. Should this be done? If so, how could it be done?

The government of Prime-Minister Koizumi Junichiro (2001-2006) led the revisionist movement with a more nationalist agenda ${ }^{6}$. The solution was to include those changes in the "War on Terror". After September 11, Koizumi started to claim that Japan could be the next victim of terrorism and that the country should be prepared for it. The Japanese Self-Defense Forces should be ready for anything. Koizumi reacted right after the attack and passed a bill that enabled Japan to dispatch ships to help refuel American and coalition ships on missions to Afghanistan. It was the first time that Japanese naval forces were sent into combat since World War II and it met with little domestic opposition (Yahuda 2011, 322). Japan also helped in Iraq by sending humanitarian help and flying supplies.

6 Koizumi's period in office produced the worst Sino-Japanese relations since normalization (Hughes 2009). 
As Hughes (2004) states, the support to the War on Terror goes beyond that. Japan used terrorism as a pretext to start its "revolution." At the same time, no Asian country would be threatened by Japan's possible remilitarization. According to Hughes (2004),

Japan during the "war on terror" has been focused much more on using 11 September and the Afghan and Iraq wars as an opportunity to push forward its response to the regional and more traditional security challenges of North Korea and China, and energy security, even if at times it attempts to depict both as "new security challenges" or as involving elements of terrorism. (Hughes 2004).

It is not possible assume that the Japanese revisionism had its roots in regional security only. It is still unclear why the Japanese government adopted this new behavior. The securitization of terrorism in Japan may have had other goals and other audiences.

\section{Different ruling Parties, different Foreign Policies?}

In 2009, after more than half a century of one party domination, Japanese politics were about to change dramatically. The former opposition party, the Democratic Party of Japan (DPJ), was elected to lead the country and start a new age for the Japanese foreign policy. Hatoyama Yukio promised to forge an equal relationship with the US (regarding the Security Alliance), enhance cooperation and diplomatic efforts with China and Asia, and, last but not least, establish a more independent foreign policy. Hatoyama may be considered a neo-autonomist inside the DPJ. ${ }^{7}$

It all meant that former governments had led the country to become a discrete player in international politics. In certain ways, the Yoshida Doctrine was still alive in the politics. There were substantial changes in Japan's foreign and defense policies in the beginning of the $21^{\text {st }}$ century under LDP. Nevertheless, it was still criticized by the opposition.

Some argue that, due to Japan's subordination to the US, Japan has no real foreign policy. Japan has no room for making its own politics. Hatoyama had it

7 Weston Konishi (2012) identifies four main schools of thought of international relations among the members of DPJ: realists, pacifists, centrists, and neo-autonomists. According to him, realists in the DPJ are strongly in favor of strengthening Japan's security and defense, they have a high threat perception in regards to China and North Korea, and the alliance with the US is the best option for Japan. Pacifists support maintaining Japan's postwar Constitution and they oppose any revision to Article Nine; they have a low threat perception. Centrists tend to tilt toward the realist school, although they believe that the security challenges call for policies that do not necessarily align with the DPJ's idealistic vision; their default position is to maintain the status quo. Neo-autonomists resent Japan's strategic dependence on the United States and seek a more independent and self-empowering foreign policy; they see the US as a declining power and fear entrapment. For further details see Konishi's report From Rhetoric to Reality: Foreign-Policy Making under the Democratic Party of Japan. 
in mind. However, what could be done to strengthen the country's autonomy in international relations and, at the same time, not jeopardize vital bilateral relations with the US?

Hatoyama's most important promise was to remove the American military base from Okinawa. Internally, it had considerable political weight. Locals from Okinawa had serious complaints about the American troops and, historically, Okinawa does not feel like a real part of Japan. It has its own culture and habits. The Okinawa archipelago is 950 miles far from Tokyo. For an island-country like Japan, this distance is considerably large. The Okinawan people are seen to be physically different from the mainland Japanese. Bringing Okinawa's claims to the Diet was a step forward for Hatoyama.

It was expected from him to pursue a new foreign policy. Before taking office, he was aware of the environment in which Japan was: between the declining USA and growing China.

How should Japan maintain its political and economic independence and protect its national interest when caught between the United States, which is fighting to retain its position as the world's dominant power, and China, which is seeking ways to become dominant? (Hatoyama 2009).

Hatoyama feared that Japan could be led to a conflict by the United States, which was seen as a declining power. According to Weston Konishi (2012), he was the most prominent neo-autonomist in the Democratic Party of Japan. Hatoyama also believed that Japan should focus its foreign policy on Asia. Globalization had destroyed local communities and, under the principle of fraternity, Japan should create an East Asian Community: "Of course, the Japan-US security pact will continue to be the cornerstone of Japanese diplomatic policy." (Hatoyama 2009).

The Democratic Party of Japan had an agenda for change. The Hatoyama administration was formed by party members and outside advisers who reflected his basic worldview. Okada Katsuya, who had been critical of Japan's deferential treatment of the United States, was appointed foreign minister. Ozawa Ichiro, who was ramping up criticism of US bases on Okinawa in the lead-up to the August 2009 parliamentary elections, was appointed Secretary General (Konishi 2012). The Hatoyama administration made great efforts to improve bilateral ties with China and South Korea. Despite the differences and historical enmities, the DPJ believed that both nations would be able to move beyond their differences by setting a friendlier tone in bilateral relations (Konishi 2012).

It was clear that the US-Japan ties needed to be as important as Japan-China ties. Naturally, Washington had no good impressions about this new administration. Hatoyama wanted to change the traditional and solidified Washington-oriented foreign policy. Since the end of the occupation Japan was a faithful ally of the United States. Breaking that alliance was unimaginable. Hatoyama resigned nine 
months after taking office. He claimed that he could not keep his promises and remove the American bases from Futenma (Okinawa). This showed that, despite its political intention, Japan's Foreign Policy continues to be oriented by Washington.

The United States reacted negatively to the Hatoyama administration's mixed signals on base realignment plans, leading to major tensions in bilateral alliance relations. China and other neighboring countries in Asia also proved unreceptive to Tokyo's entreaties to form a new regional community, or even to significantly revamp diplomatic relations on a bilateral basis. (Konishi 2012).

Hatoyama's successors, Kan Naoto and Noda Yoshihiko, did not show much difference from the Hatoyama administration. Although they had different positions on the bilateral relations with the United States, both governments tried to reemphasize the centrality of the US-Japan alliance.

In September 2010, the Japanese Coast Guard arrested the captain of a Chinese fishing vessel in the waters off the Pinnacle Islands. After weeks of tension, Japan released the Chinese captain. Since then, tensions between Japan and China have become increasingly higher. The United States declared that they supported Japan, but only morally. Legally, the security of those islets should be covered by the US-Japan security treaty, but Washington showed no interest in confirming it out loud. The trend now is that the US fears entrapment and at the same time Japan fears abandonment.

\section{Abe Shinzo's second term}

In December 2012, Abe Shinzo was elected by the lower house of the Diet as Prime Minister for the second time. In early December he had been elected as the leader of the Liberal Democratic Party. He brought the party together after a three-year hiatus and got the majority in the lower House, where final decisions are made. During his campaign, he said, "I promise to protect Japan's land and sea, and the lives of the Japanese people no matter what," over the territorial dispute with China. Abe is known for his hawkish position in foreign policy. $\mathrm{He}$ is one of Japan's revisionists and was also Koizumi's successor.

Abe is a nationalist. It did not take him long to start new discussions about Japan's role in international politics. Even before the general elections in December 2012, Abe revived questions about the constitutional reform. The reform of the Constitution is one of the most controversial issues in Japanese politics. Prime Ministers such as Nakasone Yasuhiro and Nobusuke Kishi criticized the postwar constitution, but when they came into power, those ideas were abandoned. No one could lead the politics to this goal.

In December 2012, Abe published a text titled Asia's Democratic Security Diamond, which called to the Chinese naval expansion and Japan's role. In it, he 
stated that Japan should protect its territorial seas and its region from the Chinese threat. As for the Pinnacle Islets, the Abe administration seems to ignore China's claims. The dispute is not fully recognized. They recognize China as an aggressor. For the former Prime Minister Hatoyama Yukio, Japan should recognize the dispute and negotiate with China. For Abe, there is "no room for negotiation" over the status of the Senkaku islands (Miller and Yokota 2013).

Yet, increasingly, the South China Sea seems set to become a "Lake Beijing," which analysts say will be to China what the Sea of Okhotsk was to Soviet Russia: a sea deep enough for the People's Liberation Army's navy to base their nuclear-powered attack submarines, capable of launching missiles with nuclear warheads. Soon, the PLA Navy's newly built aircraft carrier will be a common sight—more than sufficient to scare China's neighbors.

That is why Japan must not yield to the Chinese government's daily exercises in coercion around the Senkaku Islands in the East China Sea. True, only Chinese law-enforcement vessels with light weaponry, not PLA Navy ships, have entered Japan's contiguous and territorial waters. But this "gentler" touch should fool no one. By making these boats' presence appear ordinary, China seeks to establish its jurisdiction in the waters surrounding the islands as a fait accompli. (Abe 2012).

Some specialists, however, argue that Abe's new foreign policy tends to be more pragmatic than hawkish. Although he has a clear opposition to China, Japan will be seeking to integrate with its region:

Abe had made clear that he considers Japan's economic relationships with China and South Korea to be of the utmost importance. Japan continues to support a potential trilateral free trade agreement among the three countries. [...] To be sure, significant obstacles stand in the way of such an agreement, but it is one from which all parties would surely benefit. (Miller and Yokota 2013).

According to Miller and Yokota (2013), Abe's campaign brought some bold remarks, which made specialists believe that his government would shift the country to the right. Nevertheless, his actions have been moderated: he started his administration by sending positive signals to China, South Korea, and Russia. It was Abe who first sent a special envoy to Seoul and he shelved the plan to elevate Takeshima Day (a regional holiday that symbolizes Japan's claim to a couple islets controlled by South Korea) to the status of a national holiday. As for Russia, Abe has made efforts to solve the territorial disputes over the Northern Territories (South Kuril Islands) by considering giving up on the claim over the largest island.

Although Abe does not advocate for a military counterbalance to China, it is difficult to assume that all of his efforts will be directed towards the economic integration with Asia. Security and defense issues cannot be overlooked. In fact, 
there is a concrete threat from China over territorial disputes which are not limited to Japan. Former Foreign Minister Gemba Koichiro stated that "China appears to be attempting to make the practice of dispatching government vessels to these areas an everyday affair and change the status quo through coercion." (Gemba 2012).

The recent Defense White Papers attest to it. China has been advancing and intensifying its military activities in waters near Japan. Whether Abe is hawkish or not will not change Japan's growing autonomy. Of course, it will set future relationships, but the state policy shall be maintained. Japan seeks its rightful place in international relations, even if it is seen as a "normal" country or not. ${ }^{8}$ The evolution of the concept of "defense" shows that the country is getting prepared or adapting itself. ${ }^{9}$

Contrary to what Jerdén and Hasgtröm (2012) state, there has always been evidence that Tokyo is reacting to China's rise, both economically and militarily. They argue that, from 1978 until 2011, Japan was conniving China's rise (Tokyo accommodated the rise of China), since Japan "allowed" China to implement its grand strategy, which consists of: 1) securing the unity of China; 2) developing the economy; 3) rising peacefully as a regional power (Jerdén and Hagström 2012). However, one cannot say that Japan accommodated China's rise because of the actions that were silently and slowly made due to the constitutional barriers in place.

\section{The Chinese dilemma and Japan's reactive role}

Previously, we stated that China will have an important role in Japan's future attitude. China will possibly set the rules of the game that Japan wants to play. It is not only a governmental policy, but a state policy. "Japanese policy-makers remain determined to marshal their national resources to secure vital interests in the face of China's rise and to not cede regional leadership easily to their Chinese counterparts." (Hughes 2009). The idea of strengthening Japan's autonomy has been crossing space and time since the end of $20^{\text {th }}$ century. Each leader has had a different way of dealing with it. But how could China set the rules? Why do the Pinnacle Islands matter?

Since 1983 Barry Buzan, Ole Waever and other authors from the Copenhagen School of Security Studies have been writing about the Security Complex. Like any other theory, it has been reformulated some times, but the underlying ideas have not been changed. In general, a Security Complex is a set of units whose processes of securitization and desecuritization are so linked that they will manifest themselves in regional clusters (Buzan and Waever 2003). The concept of securitization was

8 Some argue that Japan is not a normal country because it cannot possess Armed Forces and/or declare war. This change in Japan's attitude may be seen as the "normalization" of Japan.

9 All the official documents, such as the New National Defense Program Outline (NNDPO 1995) and the National Defense Program Guidelines (NDPG 2004; 2011), among others, show the evolution of the concept and the mutation of the capabilities of the Japan Self-Defense Forces. 
developed by Ole Waever and it claims that an issue becomes securitized when it is regarded as a critical threat by the elites. Not only is the presentation by the elites necessary, but also the acceptance from the audience. There is no standard concept for what the audience should be; it can be the population, a specific group or even the opposing politicians. Also, the securitization of an issue requires extraordinary and immediate counter-actions. It surpasses the prior sphere called "politization."

The Regional Security Complex (RSC) is not a perspective that can be applied to any group of countries. "In order to qualify as an RSC, a group of states or entities must possess a degree of security interdependence sufficient both to establish them as a linked set and to differentiate them from surrounding security regions" (Buzan and Waever 2003, 48). In 2003, Buzan and Waever published a book in which they inform that "South Asia was the foundational case study around which regional security complex theory first developed." (Buzan and Waever 2003). The Asian continent is said to bring together old-fashioned concerns about power that "still dominate the security agendas of most of the regional powers, and war remains a distinct, if constrained, possibility." (Buzan and Waever 2003).

Since East Asia can be considered a traditional RSC, the main actors (China and Japan) are sensitive to each other's movement or securitization processes. Since Japan has constitutional norms, it cannot play an active role in security relations; it can only respond to others' actions. The Chinese growth has been the main reason for Japan to develop its military. Still, one cannot forget that although the US-Japan alliance is still strong, there is a considerable chance (or fear) of abandonment.

The Pinnacle dispute is an example. Both sides are securitizing each other. The Chinese government is believed to use the media (Global Times and People's Daily newspapers) in order to encourage civilians to act aggressively and radically against Japan. As for Japan, China's "irresponsible" behavior is the main fuel (or pretext) for substantial changes and actions. The United States is not willing to use its military coercion to support Tokyo. A small armed conflict started by Beijing for those islets would be Washington's worst nightmare. Would the United States enter the conflict for Tokyo's quest for autonomy?

What is current Japan's status in international relations? There are several debates on this subject. The most famous prediction was made by Inoguchi Takashi. In 1989, Inoguchi presented four scenarios of the world system in 25-50 years' time:

a) Pax Americana Phase II, in which the United States would remain as the leading power and Japan's role would not cross the economic line.

b) Bigemony, in which Japan and the United States would manage the world economy together and both economies would be integrated. Japan's role in this scenario would change a little from those envisaged in the Pax Americana II scenario: Japan's economic power would be translated into 
military power, but through a technical-economic-strategic cooperation/ integration with the United States. Both would use its integration to jointly develop military equipment for Japanese use and also to sell to third countries.

c) Pax Consortis, in which there is no single actor who can dominate the rest. Major actors would forge coalitions to make policy adjustments and agreements among themselves. Japan's role would be that of helping to create a world free from military solutions and, regionally, Japan would promote the interests of the Asian Pacific countries.

d) Pax Nipponica, in which "Japanese economic power reigns supreme" (Inoguchi 1989). The prerequisite for the advent of this scenario is "either the removal of the superpowers' strategic nuclear arsenals or the development of an anti-nuclear defense system" (Inoguchi 1989).

According to Inoguchi (1989), Japan's autonomy in both Pax Consortis and Pax Nipponica would not be possible without the neutralization of the nuclear weapons. The United States and the Soviet Union would remain superpowers despite their economic difficulties. In his view, the superpower status is based on ownership of strategic nuclear weapons.

There are other major factors that should be seen in order to analyze all the scenarios: scientific and technological dynamism and the legacy of history. Japan would have to surpass the United States in scientific progresses. Japan's leading global role, as seen in the Pax Nipponica scenario, would not be feasible with the memory of the peoples of the nations occupied in the World War II and Inoguchi (1989) states that "Pax Nipponica is inherently difficult because of this factor."

[...] the debt of history to the Pacific Asian neighbors has been deeply felt as major constraining factor in our scenarios. It is as in an anti-Japanese alliance in Pacific Asia were always ready to be forged, despite the near half-century since the war, just because Japan once crossed a certain threshold of misconduct. (Inoguchi 1989).

Although those scenarios are admittedly incomplete, Inoguchi concludes his article by stating that Pax Americana II and Bigemony were more likely to happen in the term of 25 years, while a mixture of Pax Americana II and Pax Consortis would be more feasible in a term of 50 years. He also states that his delineation of four scenarios, including the Pax Nipponica and Bigemony, should not be understood as a disclosure of non-existent plans for Japan to become a world supreme, or co-supreme.

Takashi Inoguchi and Paul Bacon published an essay in 2006 stating that, since 2005, Japan has been developing its role as a "global ordinary power." According to Kissinger's suggestion, they argue that Japan adjusts its foreign policy 
every 15 years. ${ }^{10}$ Bacon and Inoguchi divide the postwar history of Japan into the following periods: "The contest between pro-alliance and anti-alliance sentiment (1945-1960)", "Yoshida Doctrine or free ride? (1960-1975)", "Systemic supporter of the United States (1975-1990)", "Global civilian power (1990-2005)", and "Global ordinary power (2005-2020)". There is no factual explanation to set those periods between those years, so it seems Bacon and Inoguchi followed Kissinger's idea of the 15-year-period.

According to them, Japan is currently emerging as a global ordinary power. They claim that there is greater support for the use of force inside Japan, as long as this force is used for defensive purposes. In this view, terrorism is the main reason for Japan to change its role. As a global ordinary power, Bacon and Inoguchi present three different models: the French model, the German model, and the British model. The French model brings the idea of autonomy (Gaullism); the German model brings the idea of regional embeddedness; and the British model, which they claim to be the model that Japan uses for the acquisition of ordinary power status, brings the idea of special relationship with the United Sates. ${ }^{11}$

The authors claim that if Japan wants to become an ordinary power, it must overcome legitimacy and capability deficits. The legitimacy deficit comes from the Japanese Constitution: renouncing war forever and being forbidden from using force to settle international disputes make it difficult for Japan to be a relevant power. The use of force is sometimes necessary. The capability deficit has its origins in the legitimacy deficit. Although the Self-Defense Forces have upgraded its forces since the end of the Cold War, new types of weapons and new modes of force structure have also become necessary. War potential is also necessary for defensive purposes.

Bacon and Inoguchi also state that LDP's foreign policies tend to be more aggressive than DPJ's, though both parties share some opinions. During the current period, which started in 2005, constitutional revisions are more likely to take place and are likely to take the following form: endorsement of the ordinary use of force in the settlement of international disputes, greater empowerment of the Prime Minister, greater restraints on the scope, nature, and expense of social policy, and a greater inculcation of nationalism and patriotism (Bacon and Inoguchi 2006).

Nevertheless, those models do not seem to be the best way to regard Japan's role in international relations. As Buzan and Waever (2003) wrote, the Asian continent still presents old-fashioned concerns about security. States fear each other. As Inoguchi stated in 1989, history is important. Japan is still paying for the

10 Kissinger (apud Bacon and Inoguch 2006) states that Japan is slow to respond to political developments. It normally takes Japan 15 years to respond.

11 "Both conceive themselves as distinctive and somewhat distant from their respective Continental neighbors. Both have high level of economic interdependence with the United States and are embedded in the American complex of economic relations. Both have significant alliance links with the United States." (Bacon and Inoguchi 2006). 
World War II aggression and it will not change so fast. In those models, Inoguchi and Bacon (2006) created fixed comparative models for Japan's role (though they differentiate Japan and the referential country), but we believe that Japan has its own and particular model. Due to internal pacific-norms and constitutional barriers, Japan cannot be compared to any other power. It cannot even be compared to Germany, as Asia and Europe are far too different and Germany's threats are not the same as Japan's. The legitimacy and capability deficits, if overcome, change it all. If the Constitution is somehow reformed and the Self-Defense Forces receive offensive capabilities, Japan shall not become an ordinary power. Due to its responsibilities and its impacts in regional politics, it shall assume another status.

Hughes (2009) states that Japan maintains its engagement strategy toward China by persisting in bilateral and trilateral relations with China and the United States and by emphasizing the importance of the economic power as the most effective means to influence China. We believe this strategy changed throughout the first decade of the century. It became even more evident after the Pinnacle tensions that Japan's strategy is to contain China's expansion. Tokyo tried to engage China, but the growing tensions indicate that the best Japan can do is contain its neighbor.

\section{Possible assumptions}

Regarding the new trend of the Japanese Foreign Policy, it is possible to assume two possible scenarios for Japan: Japan as a de facto great power, consequently autonomous, and Japan as a quasi-autonomous explosive power. The latter is more likely to happen. China's position will mostly determine which way Japan will go. ${ }^{12}$ For both scenarios, it is vital to set some shared elements: Japan is sensitive to all neighbors' actions and it fears abandonment from the United States.

The first assumption is that Japan shall become a complete great power. Due to the Chinese economic and military growth, there is no escape for Japan but to remilitarize and balance power against China. The United States shows no concrete commitment to the security alliance and there is a small but real chance of abandonment. As seen in the case of the Pinnacle Islands, Washington takes no place in the dispute, although it recognizes that those islands are part of the Japanese territory and must be covered by the treaty. In this case, Japan would have to emerge as a full military power with nuclear capabilities. There is no way Japan can be a complete great power without nuclear arsenals; there would be, however, impacts to the region and to the bilateral relationship with the United States. Though it would balance the continent and partially push the US away

12 There are several other elements which cannot be overlooked. The Korean Peninsula is one of them. However, in Pyongyang issues, the burden is shared with other neighbors, it does not require a direct response from Japan alone. Besides, extended nuclear deterrence, economic sanctions, and financial aid should be enough to contain threats from North Korea. The United States' commitment is also relevant. 
from the region, Washington would not approve Japan's total autonomy. If China continues to handle all disputes with such an aggressive way by threatening Tokyo economically and militarily, Japan may choose a total change.

Internally, this scenario is almost implausible, although there is a small chance that it may occur. The population's opinion is changing. Abe Shinzo said in January 2013 that he intends to revise the Constitution regarding Article Nine. Although it is almost impossible to imagine a rupture between Washington and Tokyo under LDP, Japan would be forced to have its own deterrence capabilities before it is too late. Nationalism is a growing institution in Japan and China would be an easily securitized issue due to its posture toward the Japanese people. The new generations do not tolerate verbal attacks from China or North Korea. ${ }^{13}$ Also, Japan has the financial and technological conditions to go nuclear and possesses what is called by Buzan and Waever (2003) "recessed deterrence", which is the capability to move quickly to Nuclear Weapon State status. Kenneth Waltz (2008) argues that Japan is pressed by China and other nuclear states to react and he predicts that Japan shall develop its nuclear weapons. It is only a matter of time.

Any country in Japan's position is bound to become increasingly worried about its security, the more because China is rapidly becoming a great power in every dimension: internal economy, external trade, and military capability. [...] Japanese nuclear inhibitions arising from World War II will not last indefinitely. India, Pakistan, China, and perhaps North Korea have nuclear weapons capable of deterring others from threatening their vital interests. How long can Japan live alongside other nuclear states while denying itself similar capabilities? (Waltz 2008).

Nevertheless, going nuclear has its price. Although Japan feels safer and autonomous, Scott Sagan argues that new nuclear countries are a threat to other nuclear countries, so there may be a risk of conflict. "Whenever a new state is seen to be developing nuclear weapons, it is likely that its rivals will consider preventive war under this 'better now than later' logic." (Sagan 2002). In the case of Japan, going nuclear may jeopardize all its relations with its neighbors and globally. Japan has signed the Non-Proliferation Treaty and the possession of such weapons would undermine its global relations. The fear over the rebirth of the Japanese empire would make Japan a pariah state in Asia, if it is not already one. "Japan might thus be returned to its long-feared scenario of having to fend for its own security and undertake full remilitarization, which would lead it into a destructive downward-spiralling security dilemma with China.” (Hughes 2009). If security is the only and most important element for the Japanese state (which we do not believe it is), nuclear weapons are a good option. Once it starts its

13 Asahi Shimbum interviewed the people of Japan in April 2009 and 51\% of them approved the constitutional reform. 
nuclear development without American authorization, Japan cannot rely on the United States to face China or other power until it is ready.

What makes this assumption feasible is that Japan can do it all in silence. It does not have to reform its constitution. The ambiguity of Article Nine makes all the changes possible. The Japanese government after 2001 showed that the Constitution is like a play-dough in the hands of a child. It can forbid or permit actions depending on the support the government has in the Diet. Nuclear weapons are a great way to dissuade enemies from attacking, so it may be defensive only. One can assume that the main purpose of the nuclear weapons is the deterrence, not the use. Not only would nuclear weapons be allowed, but war heavy equipment, such as nuclear submarines, long-range fighters, stealth aircrafts, and aircraft carriers, among others, would be allowed as well. In 2009, the Japan Maritime Self-Defense Force incorporated a Hyuuga-class helicopter destroyer (16DDH), which is believed to be a light aircraft carrier. It is allowed by the Constitution. In August 2013, Japan unveiled a new destroyer (22DDH) to be commissioned into the fleet in 2015, which is also regarded as an "aircraft carrier in disguise." Naturally these new destroyers are an object of concern for the Asian neighbors.

The second scenario foresees Japan as an explosive power, which is more likely to happen. The Pinnacle Islands and the aggressive Chinese attitudes show that Japan is not fully respected by the Chinese. Due to the importance of economic ties with its neighbors, Japan cannot respond aggressively. In this scenario, the Constitution would remain as it is and the security alliance with Washington would still be a pillar of the Japanese security, though it would not be fundamental. Should Washington abandon Tokyo, Japan will be able to protect itself. This is why we call it "explosive." Japan can become a complete great power at any time, but only if it is the last choice left. How could the alliance between Japan and the United States not be fundamental for Japan? If Japan continues to expand its conventional capabilities under the constitution as it is already doing, someday it will be less dependent on the United States, since it already dissuades conventional threats.

Besides, the American protection would be necessary against nuclear threats only. These days, the chance of a nuclear threat is low, although it is not impossible. It will certainly be an irrational action if China uses or threatens to use its nuclear weapons on Japan. What would make things even worse is that China would threat a non-nuclear state. It is possible to say that the same happens to North Korea. Any use of nuclear weapons would determine the likely annihilation of its regime.

In the second scenario, Japan would be a quasi-autonomous state. Washington would still influence Japan's foreign policy, but it would not be so assertive. For Japan, the best thing to do would be to remain in the alliance but act like it did not exist. The Self-Defense Forces should be strengthened in slow but large steps. Japan would be an ordinary power and it would have the chance to choose the right moment to become a complete great power if it was necessary. As an 
explosive power, Japan would be more autonomous and all the threats would be repelled by its conventional forces and by the security alliance with the United States. If China accepts to handle all the conflicts with Japan in a less-threatening way, Japan has no reason to remilitarize itself at all. What makes it feasible is that the Japanese government has been taking measures to become more independent from the United States, although the alliance is still regarded as fundamental.

As for China, it is able to set the rules of this game. Japan will choose its character depending on these rules. If the rules are strict, Japan will respond to it. As Kissinger once stated, it may take 15 years for Japan to respond, but it will. China often claims that Japan is unbalancing the region by bringing an extraregional power to Asia through a military alliance. The American military bases in Japan may threaten China directly, but it apparently prevents Japan to become a complete great power. What would happen if the alliance was denounced? Japan would surely become a complete great power under its possibilities. What should China stand for?

Both scenarios predict a stronger Japan in its China containment strategy. As Hughes (2009) argues, "there are risks of exacerbating regional tensions with China, and less apparent but even greater risks of stimulating tensions between Japan and both China and the US." If Japan's increasing autonomy is a threat for China and other neighbors (and the United States), it may be considered a "train wreck" in Asia, but not because it will destroy itself. The situation is the following: two trains are on the same rails toward each other. You know that they will crash; you cannot avoid the clash, you can only watch it happen. It all means that Japan's strengthening will happen somehow. There is nothing to do in order to avoid it. It is foreseeable but unavoidable. And, perhaps, disastrous.

\section{Bibliographic references}

ABE, S. Asia’s Democratic Security Diamond. Project Syndicate. Available at: http://www. project-syndicate.org/commentary/a-strategic-alliance-for-japan-and-india-by-shinzo-abe. Accessed on February 10th 2012.

ASAHI SHINBUM. Panetta tells China that Senkakus under Japan-U.S. Security Treaty. September $21^{\text {st }}$ 2012. Available at: http://ajw.asahi.com/article/asia/china/AJ201209210061. Accessed on February 10th 2012.

BUZAN, B.; WAEVER, O. Regions and Powers: the structure of international security. New York: Cambridge University Press, 2003.

BACON, P.; INOGUCHI, T. Japan's emerging power as a 'global ordinary power'. International Relations of the Asia-Pacific. Vol. 6, 2006.

CHRISTENSEN, T. China, the US-Japan Alliance and the Security Dilemma in East Asia. International Security, Vol. 23, Nr. 04, 1999. 
DOBSON, Hugo; GILSON, Julie; HOOK, Glenn; HUGHES, Christopher. Japan's international relations: politics, economics and security. Oxon: Routledge, 2005.

2012.

. Japan's international relations: politics, economics and security. Oxon: Routledge,

DOWER, John. Embracing Defeat: Japan in the Wake of World War II. New York: W.W. Norton \& Co., 2000.

Empire and Aftermath: Yoshida Shigeru and the Japanese Experience 1878-1954.

Cambridge: Harvard University Press, 1988.

GEMBA, Koichiro. Japan-China relations at a crossroads. International Herald Tribune. November 212012.

HATOYAMA, Y. A New Path for Japan. New York Times. August 26 2009. Available at: http://www.nytimes.com/2009/08/27/opinion/27iht-edhatoyama.html? pagewanted=all. Accessed on February $10^{\text {th }} 2013$.

HUGHES, C. Japan's response to China's rise: regional engagement, global containment, dangers of collision. International Affairs, $\operatorname{Vol} 85, \mathrm{Nr}$ 4, 2009.

Press, 2004.

. Japan's re-emergence as a 'normal' military power. Oxford: Oxford University

INOGUCHI, T. Four Japanese scenarios for the future. International Affairs, 1989.

JERDÉN; HAGSTRÖM, 2012. Rethinking Japan's China Policy: Japan as an Accommodator in the Rise of China, 1978-2011. Journal of East Asian Studies, 12, 2012.

KENNEDY, P. The rise and fall of the Great Powers. New York: Random House, 1989.

KONISHI, Weston. From Rhetoric to Reality: Foreign Policy making under the democratic party of Japan.

MILLER; YOKOTA. Japan Keeps its cool. Foreign Affairs. January 2013.

NEW YORK TIMES. Anti-Japan Protests Erupt in China Over Disputed Island. August 19th 2012. Available at: http:/www.nytimes.com/2012/08/20/world/asia/japanese-activists-displayflag-on-disputed-island.html?pagewanted=all\&_r=0. Accessed on February 10th 2012.

SAGAN, Scott; WALTZ, Kenneth. The spread of Nuclear Weapons: a debate renewed. New York: Norton, 2002.

SUGITA, 2003, Yoneyuki. Pitfall or Panacea: The irony of US Power in Occupied Japan: 1945-1952. New York: Routledge. 2003.

WALTZ, Kenneth. Realism and International Politics. New York: Routledge, 2008.

YAHUDA, Michael. The International Politics of Asia-Pacific. Oxon: Routledge, 2011.

YOSHIDA, S. Last Meiji Man. Lanham: Rowman \& Littlefield, 1961.

Submitted March 7, 2014

Accepted April 29, 2014 


\section{Abstract}

Recently, Japan has been increasing tensions with China regarding the Pinnacle Senkaku/Diaoyu islands. Due to the Chinese military development, Japan has been working on its political and military strengthening in Asia. This essay presents two possible scenarios for Japan.

Keywords: Asia-Pacific; China; Japan; Security; United States.

\section{Resumo}

Recentemente, o Japão tem aumentado as tensões com a China com relação às ilhas Pinnacle/ Senkaku/Diaoyu. Por causa do desenvolvimento militar chinês, o Japão tem trabalhado no seu fortalecimento político e militar na Ásia. Este artigo apresenta dois possíveis cenários para o Japão.

Palavras-chave: Pacífico Asiático; China; Japão; Segurança; Estados Unidos. 